\title{
Tree-Substrate Water Relations and Root Development in Tree Plantations Used for Mine Tailings Reclamation
}

\author{
Marie Guittonny-Larchevêque, ${ }^{*}$ Bruno Bussière, and Carl Pednault
}

\begin{abstract}
Tree water uptake relies on well-developed root systems. However, mine wastes can restrict root growth, in particular metalliferous mill tailings, which consist of the finely crushed ore that remains after valuable metals are removed. Thus, water stress could limit plantation success in reclaimed mine lands. This study evaluates the effect of substrates varying in quality (topsoil, overburden, compost and tailings mixture, and tailings alone) and quantity $\left(50-\right.$ or $20-\mathrm{cm}$-thick topsoil layer vs. $1-\mathrm{m}^{2}$ plantation holes) on root development and water stress exposure of trees planted in low-sulfide mine tailings under boreal conditions. A field experiment was conducted over 2 yr with two tree species: basket willow (Salix viminalis L.) and hybrid poplar (Populus canadensis Moench $\times$ Populus maximowiczii A. Henry). Trees developed roots in the tailings underlying the soil treatments despite tailings' low macroporosity. However, almost no root development occurred in tailings underlying a compost and tailings mixture. Because root development and associated water uptake was not limited to the soil, soil volume influenced neither short-term (water potential and instantaneous transpiration) nor long-term $\left(\delta^{13} \mathrm{C}\right)$ water stress exposure in trees. However, trees were larger and had greater total leaf area when grown in thicker topsoil. Despite a volumetric water content that always remained above permanent wilting point in the tailings colonized by tree roots, measured foliar water potentials at midday were lower than drought thresholds reported for both tested tree species.
\end{abstract}

\section{Core Ideas}

- Planted trees developed roots in the tailings underlying the soil treatments.

- Root development was limited in tailings underlying a compost and tailings mixture.

- Trees were larger and had greater total leaf area when grown in thicker topsoil.

- Trees showed low foliar water potential despite root access to tailings water reserve.

- The volume of the soil treatment did not affect tree foliar water potentials.
Copyright $\odot$ American Society of Agronomy, Crop Science Society of America, and Soil Science Society of America. 5585 Guilford Rd., Madison, WI 53711 USA. All rights reserved.

J. Environ. Qual. 45:1036-1045 (2016)

doi:10.2134/jeq2015.09.0477

This is an open access article distributed under the terms of the CC BY-NC-ND license (http://creativecommons.org/licenses/by-nc-nd/4.0/).

Received 22 Sep 2015.

Accepted 8 Dec 2015.

*Corresponding author (marie.guittonny-larcheveque@uqat.ca).
$\mathrm{W}$ ATER STRESS is often reported as a possible explanation for plantation failure in reclaimed mine lands (Moffat, 1995; Hutchings et al., 2001; Nicoll et al., 2006). Tree water uptake relies on well-developed root systems, but certain characteristics of mine substrates can prohibit root growth: no structure, no organic matter, extreme $\mathrm{pH}$, elevated electrical conductivity, and trace metal concentrations (Tordoff et al., 2000; Burger and Zipper, 2002). However, studies dealing with plantations to reclaim mine wastes often evaluate revegetation success based on aboveground productivity (Drake, 1986; Kost et al., 1998; Angel et al., 2006; Emerson et al., 2009; Landhäusser et al., 2012; Sloan and Jacobs, 2013; Mosseler et al., 2014) and rarely account for tree root development. Moreover, only a few available studies examine tree planting in metalliferous mine tailings (Bjugstad, 1986; Renault et al., 2008; Boyter et al., 2009; Asensio et al., 2011; Larchevêque et al., 2013, 2014).

Among mine wastes, metalliferous mill tailings consist of the finely crushed ore $(70-80 \%$ of particles between 2 and 80 $\mu \mathrm{m})$ (Aubertin et al., 2002) that remains after valuable metals are removed. They are transported from the mine plant usually by pumping with water and deposited as slurry in tailings storage facilities. Among milling wastes, thickened tailings (Robinsky et al., 1991) have a solid content of 50 to $70 \%$ (on a mass basis) when deposited. Their basic properties are similar to those of conventionally deposited tailings (slurried) (Bussière, 2007), but they have a more uniform (homogeneous) grain size distribution in the tailings facility ( $\mathrm{Al}$ and Blowes, 1999). In metalliferous mine tailings, root development seems restricted to cover soils (Borgegard and Rydin, 1989; Zhang et al., 2001; Larchevêque et al., 2013), probably because the underlying tailings have unsuitable properties for root growth (Meredith and Patrick, 1961; Evanylo et al., 2005; Michels et al., 2007), in particular low airfilled porosity (Larchevêque et al., 2013). Impeded root development may result in tree exposure to water stress despite tailings' richness in water due to low hydraulic conductivities $\left(k_{\text {sat }}=10^{-6}\right.$ to $10^{-8} \mathrm{~m} \mathrm{~s}^{-1}$ ) (Barbour et al., 1993; Aubertin et al., 1996).

Efficient root systems optimize the contact surface with the substrate and the explored volume of substrate. Fine roots (i.e.,

M. Guittonny-Larchevêque and B. Bussière, Université du Québec en AbitibiTemiscamingue - Research institute in mines and the environment, 445 , boul. de I'Université, Rouyn-Noranda, Québec J9X 5E4, Canada; C. Pednault, Canadian Malartic Mine, 100, chemin du Lac Mourier, Malartic, Québec JOY 1Z0, Canada. Assigned to Associate Editor Clinton Williams.

Abbreviations: MS20, treatment of $20 \mathrm{~cm}$ mineral soil mixed with compost; RLD, root length density; SRL, specific root length; SSA, specific surface area; $T$, tailings alone treatment; $\mathrm{TC}$, compost and tailings mixture treatment; TS20, topsoil layer 20 $\mathrm{cm}$ treatment; $\mathrm{TS} 50$, topsoil layer $50 \mathrm{~cm}$ treatment; TSho, topsoil plantation holes treatment; VWC, volumetric water content. 
diameter $<1 \mathrm{~mm}$ ) are the most active part of the root system in water uptake (Leuschner et al., 2004). When adapted plants are water stressed, they can increase the surface contact with the substrate with a relatively small decrease in fine root diameter and an increase in their specific root length (SRL) (i.e., root length per dry mass), specific surface area (SSA) (i.e., root surface area per dry mass), root length density (RLD) (i.e., root length by unit of soil volume), or proportion of fine to coarse roots, especially at depths in soil where water is available (Comas et al., 2013). Root mycorrhizae, frequently observed in boreal forests (Read et al., 2004), also greatly participate in water uptake by increasing the contact surface of the root system with the substrate (Garg and Chandel, 2010). Poplar (Populus sp.), a pioneer tree species of Canadian boreal region, may be an interesting indicator of water stress exposure on mine wastes because its growth is very sensitive to water availability (van den Driessche, 1999; Larchevêque et al., 2011).

In low-sulfide tailings, the toxicity of trace metals toward plant roots may be limited (Bagatto and Shorthouse, 1999; Trüby, 2003) because acidification is limited. Thus, adapted trees could be directly planted in low-sulfide tailings. The sulfide minerals of the tailings, like pyrite, react with water and oxygen when exposed to atmospheric conditions to produce sulfuric acid. Acidification of the tailings increases trace metal mobility toward the plant-available fraction. Willow (Salix sp.) is one of the first species to colonize mine wastes (Gibson, 1982) and seems well adapted to plantation on mine substrates (Mosseler et al., 2014; Mosseler and Major, 2014). In new mine projects, however, topsoil (i.e., superficial soil containing organic matter) and overburden (i.e., soil overlying bedrock) are usually saved for revegetation purposes (Cooke and Johnson, 2002). They are used above tailings to create an appropriate substrate for plant root development. Because the use of soil layers above tailings may reduce evaporation from the tailings' surface, water saturation of tailings under soil layers may be greater, and aeration lower, than that of tailings without soils. This may affect water availability and tree root growth in tailings under soils.

The available quantity of topsoil is often limited compared with the vast mine surfaces that require revegetation. Thus, the thickness of the layers of topsoil used and the area of the treated surfaces are likewise limited, and complementary solutions using overburden and amendments are necessary. Several studies showed that mine wastes used in combination with low-cost organic amendments, such as sewage sludge, domestic refuse, peat, or topsoil were suitable substrates for plant growth (Tordoff et al., 2000). Tailings mixtures with amendments have increased air-filled porosity and decreased density (Larchevêque et al., 2012) that may favor root development.

The main objective of this study was to evaluate the effect of substrates varying in quality (topsoil, overburden, compost and tailings mixture, and tailings alone) and quantity (50- or $20-\mathrm{cm}$ thick topsoil layer vs. $1-\mathrm{m}^{2}$ plantation holes) on root development and water stress exposure of trees planted in low-sulfide mine tailings under boreal conditions. It was previously demonstrated in a greenhouse experiment that the used tailings had no trace element toxic effects on basket willow and a $\mathrm{DN} \times \mathrm{M}$ poplar clone (Larchevêque et al., 2013). A 2-yr field experiment was conducted with these same two trees. All trees were fertilized with mineral $\mathrm{N}$ and $\mathrm{P}$ at planting to limit the effects of varying availability of nutrients among substrates on trees. Our working hypotheses were that (i) trees would not survive when directly planted in the tailings, even with mineral fertilization, due to low air-filled porosity of the tailings, which impedes root growth; (ii) the presence of soil layers above tailings would increase the tailings' volumetric water content (VWC) due to limited evaporation; (iii) trees would not develop any root in the tailings under the soil or amendment layers due to their low air-filled porosity; and (iv) the more limited the available volume of soil for tree root growth (i.e., from plantation holes to thin and thick soil layers), the more trees would be exposed to water stress.

\section{Materials and Methods}

\section{Site Description}

The Canadian Malartic gold mine in Malartic, Quebec, Canada $\left(48^{\circ} 13^{\prime} \mathrm{N}, 78^{\circ} 12^{\prime} \mathrm{W}\right.$; property of Canadian Malartic GP) is a large open-pit mine that began production in 2011. It is located in the Northern Clay Belt region of Quebec and Ontario. Typical forest vegetation surrounds the mine and includes jack pine (Pinus banksiana Lamb.), black spruce [Picea mariana (Mill.) Britton], trembling aspen (Populus tremuloides Michx.), white birch (Betula papyrifera Marsh.), tamarack or eastern larch [Larix laricina (Du Roi) K. Koch], and balsam fir [Abies balsamea (L.) Mill.]. In this boreal region, the growing season typically begins in mid-May and ends in early October, with a mean temperature during the three warmest months (June, July, and August) of around 18 or $19^{\circ} \mathrm{C}$. Average annual temperature is $1^{\circ} \mathrm{C}$, and the average number of frost-free days is 80 . Mean annual precipitation is approximately $900 \mathrm{~mm}$ (Government of Canada, 2004).

\section{Tailings, Soils, and Compost}

Canadian Malartic ore is a mineralized greywacke. The tailings are low in sulfide (around 1\% S) and contain calcite, which can neutralize acidity. The tailings consist of finely milled wastes ( $86 \%$ particles $<80 \mu \mathrm{m}$ ) from the gold extraction process (cyanide leaching). They were deposited in the facility as thickened tailings (around $60 \%$ of solids in mass) less than 6 mo before the experiment took place. The tailings had undergone a cyanide destruction process $\left(\mathrm{SO}_{2} / \mathrm{O}_{2}\right.$ technology) that left free $\mathrm{CN}^{-}$ concentrations lower than $20 \mathrm{mg} \mathrm{kg}^{-1}$. The tailings' chemical characteristics are reported in Table 1 . They have trace metal concentrations below the Quebec regulation thresholds for residential lands, except for total $\mathrm{Cd}$, which appears slightly above the threshold $\left(5 \mathrm{mg} \mathrm{kg}^{-1}\right)$.

Tailings were transported by truck from the tailings facility to the experimental zone in April 2012 and deposited above older tailings. The experimental cell was $120 \mathrm{~m} \times 50 \mathrm{~m}$ and was contained by waste rock walls $(0.5-1.5 \mathrm{~m}$ high) covered with a geotextile liner, which allowed water drainage but retained tailings.

The overburden soil used to cover the mine wastes was a luvic gleysol (Agriculture and Agri-Food Canada, 2010). The overburden topsoil consisted of the uppermost $30 \mathrm{~cm}$ of dark (organicrich) soil layers ( $\mathrm{O}$ and $\mathrm{A}$ horizons) that had been set aside before excavation of the open pit. The overburden subsoil consisted of the remaining mineral sandy clay loam that was excavated down to bedrock after the overburden topsoil had been removed. Overburden topsoil and mineral soil were stocked for 24 to 36 
mo in separated piles of $7 \mathrm{~m}$ high with a 2.5:1 slope. During storage, the piles were seeded with fast-growing herbaceous species to protect the soils from erosion. The greenwastes' compost used as an amendment to improve the mineral soil and the tailings' structure came from the St-Henri-de-Lévis facility in Quebec (Biogénie). It was principally made from leaves and lawn residues as well as a small proportion of small branches and tree bark. It was sieved to $1.25 \mathrm{~cm}$ before use. Soils and compost characteristics are presented in Table 1.

\section{Plant Material and Growth Conditions}

Trees were adapted to boreal conditions and locally produced by the Ministère de l'Énergie et des Ressources Naturelles du Québec. Hybrid poplar and willow stock consisted of clonally propagated 1-yr-old whips (1-m-long cuttings) from Populus canadensis Moench $\times$ Populus maximowiczii A. Henry $(\mathrm{DN} \times \mathrm{M}$, clone number 916004) and Salix viminalis L. (basket willow).

The field experiment was set up on thickened tailings in midJune 2012. Unrooted whips were planted to a depth of $30 \mathrm{~cm}$ in the soil or the tailings. All trees were fertilized at planting with $15 \mathrm{~g}$ ammonium nitrate (34.5-0-0) and $15 \mathrm{~g}$ triple superphosphate (0-45-0) by placed fertilization (van den Driessche, 1999), which involved inserting the fertilizer into a slit made with a spade near the base of each tree, $20 \mathrm{~cm}$ from the tree and $15 \mathrm{~cm}$ deep.

\section{Experimental Design}

A split-plot design was used: 18 experimental plots $=3$ blocks (replicates) $\times 6$ treatments (whole plot factor) $\times 2$ tree species (subplot factor: $\mathrm{DN} \times \mathrm{M}$ poplar, basket willow) $\times 9$ trees per factor combination (pseudo-replicates). The six substrate treatments are represented in Fig. 1 and are defined as follows: MS20, $20 \mathrm{~cm}$ overburden mineral soil layer and compost; T, direct planting in tailings; TC, tailings mixed with compost; TS20, $20 \mathrm{~cm}$ overburden topsoil layer; TS50, $50 \mathrm{~cm}$ overburden topsoil layer; and TSho, plantation holes filled with topsoil. Each plot covered $11 \mathrm{~m} \times 11 \mathrm{~m}$ and was separated from the others by a 3-m-wide zone of bare tailings. Tree spacing was $1 \mathrm{~m} \times 1 \mathrm{~m}$, and a 3 - $\mathrm{m}$ buffer zone was kept free of trees at the edge of the different treatments. However, for the MS20 and TSho treatments, trees were spaced at $2 \mathrm{~m} \times 2 \mathrm{~m}$ to separate the $1-\mathrm{m}^{2}$ plantation holes, resulting in a $16 \mathrm{~m} \times 16 \mathrm{~m}$ plot size. The soil layers (TS50, TS20, MS20) were applied on the tailings by a mechanical shovel in May 2012. The mineral soil (MS20) was then mixed with $0.1 \mathrm{~m}^{3}$ of fresh greenwaste compost (corresponding to $65 \mathrm{~kg}$ and a proportion of $23 \%$ of compost in the mix on a dry mass basis) by a mechanical shovel in $1 \mathrm{~m}^{2} \times 20 \mathrm{~cm}$ deep plantation holes. For the TSho treatment, plantation holes $\left(1 \mathrm{~m}^{2} \times 20 \mathrm{~cm}\right)$ were dug in tailings and filled with topsoil by a mechanical shovel. Finally, the TC treatment consisted of a 6-cm-thick layer of compost superficially deposited

Table 1. Initial soil, tailings, and compost characteristics.

\begin{tabular}{|c|c|c|c|c|c|}
\hline Characteristics & Overburden topsoil & Overburden mineral soil & Compost & Tailings & $\begin{array}{c}\text { Regulation thresholds } \uparrow \\
\text { (residential lands) }\end{array}$ \\
\hline$\overline{\mathrm{pH}}$ & $5.1(0.1) \neq$ & $7.2(0.1)$ & $6.7(0.01)$ & $7.9(0.1)$ & \\
\hline Clay,§ \% & $42(5)$ & $33(5)$ & & $12(1)$ & \\
\hline Silt,,$\%$ & $27(1)$ & $15(1)$ & & $50(1)$ & \\
\hline Organic matter, $\%$ & $17(3)$ & $1.1(3)$ & $41(1)$ & $0.1(2)$ & \\
\hline $\mathrm{C} / \mathrm{N}$ & $22(7)$ & $17(5)$ & $20(2)$ & $4(1.5)$ & \\
\hline Electrical conductivity & $7(1)$ & $10(1)$ & $21(0.5)$ & $10(1)$ & \\
\hline $\mathrm{N}, \mathrm{g} \mathrm{kg}^{-1}$ & $4.3(0.3)$ & $0.4(0.3)$ & $12(1)$ & $0.1(0.5)$ & \\
\hline $\mathrm{Pg} \mathrm{kg}^{-1}$ & $0.6(0.04)$ & $0.6(0.04)$ & $2.5(0.2)$ & $0.7(0.01)$ & \\
\hline Available $\mathrm{P}, \mathrm{mg} \mathrm{kg}^{-1}$ & $3.6(0.7)$ & $5.1(0.7)$ & $252(7)$ & $8(5)$ & \\
\hline $\mathrm{K}, \mathrm{g} \mathrm{kg}^{-1}$ & $3.6(0.05)$ & $2.7(0.05)$ & $6.5(0.2)$ & $9(0.4)$ & \\
\hline $\mathrm{Ca}, \mathrm{g} \mathrm{kg}^{-1}$ & $11(1)$ & $9(1)$ & $31(1.3)$ & $17(2)$ & \\
\hline$M g, \mathrm{gg}^{-1}$ & $11(0.1)$ & $11(0.1)$ & $4(0.01)$ & $14(0.6)$ & \\
\hline $\mathrm{Na}, \mathrm{g} \mathrm{kg}^{-1}$ & $0.3(0.02)$ & $0.4(0.02)$ & $0.4(0.01)$ & $0.5(0.05)$ & \\
\hline $\mathrm{Al}, \mathrm{g} \mathrm{kg}^{-1}$ & $17(1)$ & $13(1)$ & $3.5(0.3)$ & $14(1)$ & \\
\hline $\mathrm{Fe}, \mathrm{g} \mathrm{kg}^{-1}$ & $27(2)$ & $24(2)$ & $9(0.3)$ & $34(2)$ & \\
\hline $\mathrm{B}, \mathrm{mg} \mathrm{kg}^{-1}$ & $6.3(0.3)$ & $3.9(0.3)$ & $21(0.6)$ & $0.8(0.5)$ & \\
\hline As, $\mathrm{mg} \mathrm{kg}^{-1}$ & $7.7(0.5)$ & $5.7(0.5)$ & $5(0.8)$ & $5.4(1.4)$ & 30 \\
\hline $\mathrm{Cd}, \mathrm{mg} \mathrm{kg}^{-1}$ & $0.6(0.15)$ & $0.4(0.15)$ & $2(0.07)$ & $6(0.2)$ & 5 \\
\hline $\mathrm{Co}, \mathrm{mg} \mathrm{kg}^{-1}$ & $5.8(0.4)$ & $6.0(0.4)$ & $1.0(0.15)$ & $5.9(1.5)$ & 50 \\
\hline $\mathrm{Cr}, \mathrm{mg} \mathrm{kg}^{-1}$ & $120(14)$ & $116(14)$ & $10(0.1)$ & $168(10)$ & 250 \\
\hline $\mathrm{Cu}, \mathrm{mg} \mathrm{kg}^{-1}$ & $58(12)$ & $31(12)$ & $42(4)$ & $52(2)$ & 100 \\
\hline $\mathrm{Mn}, \mathrm{mg} \mathrm{kg}^{-1}$ & $344(26)$ & 367 (26) & $427(11)$ & $441(16)$ & 1000 \\
\hline Mo, $\mathrm{mg} \mathrm{kg}^{-1}$ & $2.3(0.2)$ & $1.6(0.3)$ & $1.1(0.4)$ & $8.6(0.6)$ & 10 \\
\hline $\mathrm{Ni}, \mathrm{mg} \mathrm{kg}^{-1}$ & $64(7)$ & $51(7)$ & $11(1)$ & $69(9)$ & 100 \\
\hline $\mathrm{Pb}, \mathrm{mg} \mathrm{kg}^{-1}$ & $22(4)$ & $13(4)$ & $24(1)$ & $18(100)$ & 500 \\
\hline $\mathrm{Zn}, \mathrm{mg} \mathrm{kg}^{-1}$ & $83(5)$ & $62(5)$ & $151(5)$ & $73(4)$ & 500 \\
\hline
\end{tabular}

† Source: Government of Quebec (2016).

$\neq$ Values are mean $(\mathrm{SE})(n=3)$. All values are expressed on a dry matter basis.

$\S$ Particles $<2 \mu \mathrm{m}$.

ๆ Particles $<50 \mu \mathrm{m}$. 

a) MS20
b) TC
c) $T$
d) TS50
e) TS20
f) TSho

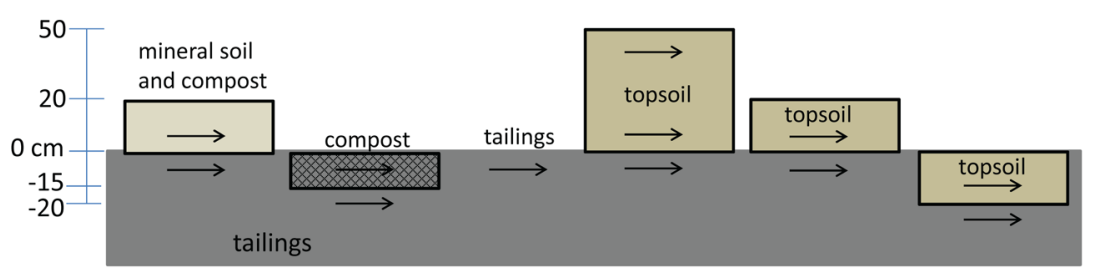

Fig. 1. Schematic representation of substrate treatments tested in the study with their respective ECH2O probes positioning. (a) Twenty centimeter mineral soil mixed with compost (MS20). (b) Compost and tailings mixture (TC). (c) Tailings alone (T). (d) Topsoil layer $50 \mathrm{~cm}$ (TS50). (e) Topsoil layer 20 $\longrightarrow \mathrm{ECH}_{2} \mathrm{O}$ probe $\mathrm{cm}$ (TS20). (f) Topsoil plantation holes (TSho).

above tailings and mixed at $15 \mathrm{~cm}$ depth by a compact loader (T110, Bobcat Co.) equipped with a rotovator. The compost amendment corresponded to $179 \mathrm{t} \mathrm{ha}^{-1}$ of dry compost and to a proportion of $13 \%$ of compost in the mix on a dry mass basis. Compost rates were calculated to provide around $4 \%$ of organic matter in the mixtures to improve the tailings and the overburden structure by providing a better infiltration rate and lower density (Peters, 1995; Marcus, 1997; Bendfeldt et al., 2001).

\section{Measurements, Sampling, and Analysis}

\section{Substrate Measurements}

Three random samples were taken at planting (June 2012) for soils, tailings, and compost characterization (Table 1 ) at 0 to $10 \mathrm{~cm}$ depth. Analyses were conducted on sieved ( $2 \mathrm{~mm}$ mesh), finely ground, oven-dried samples $\left(50^{\circ} \mathrm{C}\right)$ (Lakehead University Centre for Analytical Services,). Total N was analyzed by the Dumas combustion method (CNS 2000, LECO) and organic carbon (C) by thermogravimetric method (LECO-TGA,). Organic matter concentrations were calculated as $1.72 \times$ organic C. After $\mathrm{HNO}_{3}-\mathrm{HCl}$ digestion, sample concentrations of total $\mathrm{P}, \mathrm{K}, \mathrm{Ca}, \mathrm{Mg}, \mathrm{Na}, \mathrm{Al}, \mathrm{As}, \mathrm{B}, \mathrm{Cd}, \mathrm{Co}, \mathrm{Cr}, \mathrm{Cu}, \mathrm{Fe}, \mathrm{Mn}, \mathrm{Ni}, \mathrm{Pb}, \mathrm{Sr}$, and $\mathrm{Zn}$ were determined by inductively coupled plasma-atomic emission spectrometry (Vista PRO, Varian Canada). Available P was determined in a sodium bicarbonate solution using spectrophotometry (Olsen et al., 1954). Finally, pH was determined in a saturated paste extract, and electrical conductivity was determined in 1:2 water solution. Soil texture was determined using the Bouyoucos hydrometer method (Bouyoucos, 1962).

Undisturbed $100-\mathrm{cm}^{3}$ substrate samples were taken with a double cylinder soil sampler at 0 to $10 \mathrm{~cm}$ in each plot in July 2012 to characterize each treatment: one by tree species, taken at the foot of the fifth tree on each plot (one sample by tree species and treatment; $n=36$ ). Additional samples were taken at the same location to measure permanent wilting point, electrical conductivity, and organic matter concentration. Water retention properties of the substrates were determined using procedures proposed by Klute (1986) and Cassel and Nielsen (1986). Undisturbed substrate samples $\left(5 \mathrm{~cm}\right.$ diameter, $\left.100 \mathrm{~cm}^{3}\right)$ were brought to saturation in the lab under vacuum and weighed (W1). They were set on the porous surface of a sand box apparatus (Eijkelkamp Agrisearch Equipment) and brought to equilibrium with a tension value of $-10 \mathrm{kPa}$ (field capacity). They were weighed (W2) and oven dried $\left(105^{\circ} \mathrm{C}, 48 \mathrm{~h}\right)$ before weighing one last time (W3). Total porosity (\%), macroporosity or airfilled porosity (\%), and bulk density $\left(\mathrm{g} \mathrm{cm}^{-3}\right)$ were estimated with the following formulas:

Total porosity $=(\mathrm{W} 1-\mathrm{W} 3) / 100 \mathrm{~cm}^{3} \times 100$

$$
\begin{aligned}
& \text { Macroporosity }=(\mathrm{W} 1-\mathrm{W} 2) / 100 \mathrm{~cm}^{3} \times 100 \\
& \text { Dry bulk density }=\mathrm{W} 3 / 100 \mathrm{~cm}^{3}
\end{aligned}
$$

For permanent wilting point measurements, bulk soil samples were sieved at $2 \mathrm{~mm}$ and immersed in water for $48 \mathrm{~h}$. Then they were brought to equilibrium with a tension value of $-1500 \mathrm{kPa}$ using a pressure membrane apparatus (Soilmoisture Equipment). Samples were weighed (W4) and dried for $48 \mathrm{~h}$ at $105^{\circ} \mathrm{C}$ (W5). Permanent wilting point (PWP) on a percent volume basis was estimated with the following formula:

$\mathrm{PWP}=(\mathrm{W} 4-\mathrm{W} 5) / \mathrm{W} 5 \times$ bulk density $\times 100$

EC-5 probes (Decagon Devices) were placed in the substrates in the center of each experimental plot $(n=18)$ at several depths (Fig. 1) and connected to EM-50 dataloggers to measure the VWC evolution from August 2012 to September 2013. The first 18 probes were installed $5 \mathrm{~cm}$ deep in the tailings $(5 \mathrm{~cm}$ from the surface in $T$ treatment; $5 \mathrm{~cm}$ under the treatment layer for other treatments). Fifteen other probes were installed in the treatment layers, $5 \mathrm{~cm}$ above the underlying tailings. Finally, three more probes were installed at $10 \mathrm{~cm}$ from the topsoil layer surface in the TS50 treatment. Records were set at a 1-h frequency. The probes were calibrated for each substrate type (tailings and compost mix, topsoil, clay and compost mix, and tailings). Their accuracy was $\pm 3 \%$. Mean VWC values $\left(\mathrm{mL} \mathrm{mL}^{-1}\right)$ were calculated for each week throughout the growing season (May-September) based on the hourly records. The substrate water saturation (\%) was calculated as VWC/total porosity $\times 100$.

\section{Plant Measurements}

Survival, stem height, and basal diameter were measured at planting and at the end of each growing season in 2012 and 2013 for each planted tree. On 23 Sept. 2013, the fifth tree of each treatment by species combination $(n=36)$ was harvested for aboveground biomass assessment. Trees were separated into stems and leaves. Total leaf areas of willow and poplar were measured with a LI-3100 C leaf area meter (LiCor) before drying. The plant parts were then oven dried at $50^{\circ} \mathrm{C}$ for $48 \mathrm{~h}$ and weighed. Specific leaf area (SLA; total leaf area/total leaf dry mass, $\mathrm{cm}^{2} \mathrm{mg}^{-1}$ ) was calculated.

In July 2013, tree water relations (three replicates by species $\times$ treatment; $n=36$ ) and gas exchange (poplar only, three replicates by treatment; $n=18$ ) were assessed on the fifth tree of each treatment. Then the foliage was sampled for isotope ratio $(13 \mathrm{C} / 12 \mathrm{C})$ analysis. Leaf water potential $(\mathrm{MPa})$ was measured with a pressure chamber (Model 600, PMS Instrument Co.) on one fully mature leaf per tree in the middle of the stem between 10:00 and 13:00 h on sunny days. The measurements were done on 3 
July and repeated on 5 July, without any rain between the two dates. On 5 July, instantaneous transpiration $\left(E \mathrm{i}, \mathrm{mmol} \mathrm{m}^{-2} \mathrm{~s}^{-1}\right)$ was measured on the poplars in the afternoon (13:00-15:00 h). Measurements were performed using a CIRAS-2 portable infrared gas analyzer equipped with a PLC6 broadleaf chamber illuminated by halogen lamps (photosynthetic photon flux density of $1400 \mu \mathrm{mol} \mathrm{m}^{-2} \mathrm{~s}^{-1}$ at leaf level) (PP Systems Inc.). Measurements were made on one leaf per tree at air $\mathrm{CO}_{2}$ concentration of $360 \mu \mathrm{mol} \mathrm{mol}^{-1}$ and flow at $295 \mathrm{~mL} \mathrm{~min}^{-1}$.

In July 2013, 10 to 20 fully matured leaves were sampled on the fifth tree of each treatment $\times$ species combination $(n=$ 36). Sampled foliage was oven dried $\left(50^{\circ} \mathrm{C}\right)$ and finely ground with a Brinkmann MM2 ball grinder (Brinkmann Instruments Ltd.). Stable isotope ratios (13C/12C) were determined using a Costech ECS 4010 Elemental combustion system (Costech Analytical Technologies Inc.) coupled to a continuous flow Finnigan Delta Plus Advantage IRMS (ThermoFinnigan). The relative abundance of $13 \mathrm{C}$ in leaves was expressed in terms of carbon isotope composition $(\delta 13 \mathrm{C})$ according to the following relationship: $\delta 13 \mathrm{C}=[(\mathrm{Rl}-\mathrm{Rs}) / \mathrm{Rs}] \times 1000$, where $\mathrm{Rl}$ and $\mathrm{Rs}$ refer to the $13 \mathrm{C} / 12 \mathrm{C}$ ratio in the leaf sample and in the standards, respectively. BMO (grain), CS (corn stover), and NBS $1575 \mathrm{~N}$ (pine needle) (NIST, Standard Reference Materials) were used as calibrating standards and Red Clover as working standard, with C isotope compositions of $-23.91,-12.5,-26.3$, and $-27.42 \%$ relative to Pee Dee Belemnite, respectively.

At the end of September 2013, tree roots were sampled with an 8-cm-diameter auger $\left(\right.$ core $\left.750 \mathrm{~cm}^{3}\right)$ (Eijkelkamp Agrisearch Equipment) at two depths. The first core was taken at approximately 0 to $20 \mathrm{~cm}$ and corresponded to the total depth of the thin soil layers MS20, TS20, and TSho or to the tailings mixed with compost. The second core was sampled at 20 to $30 \mathrm{~cm}$ in the tailings underlying the thin treatments or in the thick topsoil layer (TS50). Soil cores were taken on the diagonals of the square formed by the four central planted trees of each plot, one tree per species, at $40 \mathrm{~cm}$ of the tree foot on the external side of the square. A total of 36 cores $\times 2$ depths were sampled (three repetitions by tree species by treatment). Each core depth was carefully measured at sampling to calculate the core volume. In the laboratory, tree roots were washed from the soil above a fine metallic grid and separated manually from the weed roots. Scanned images of fresh roots were analyzed with Winrhizo software (regular version, Regent Instruments Inc.) for root length, surface, diameter, volume, and tip number. Then, $\operatorname{RLD}\left(\mathrm{cm} \mathrm{cm}^{-3}\right.$ of substrate), root surface density $\left(\mathrm{cm}^{2} \mathrm{~cm}^{-3}\right.$ of substrate), root volume density $\left(\mathrm{cm}^{3}\right.$ $\mathrm{cm}^{-3}$ of substrate), and number of tips density $\left(\mathrm{nb} \mathrm{cm}^{-3}\right.$ of substrate) were calculated. Finally, the root samples were oven dried at $80^{\circ} \mathrm{C}$, separated by fine $(<1 \mathrm{~mm}$ diameter) and coarse $(>1 \mathrm{~mm}$ diameter) roots, and weighed to measure root soil density ( $\mathrm{g}$ $\mathrm{cm}^{-3}$ of substrate), SSA $\left(\mathrm{m}^{2} \mathrm{~kg}^{-1}\right)$, and specific root length (SRL; $\mathrm{m} \mathrm{g}^{-1}$ ). Because few samples had roots with a diameter greater than $1 \mathrm{~mm}$, the ratio of fine to coarse roots was not calculated.

\section{Statistical Analyses}

Survival data were compared using the $\chi^{2}$ test. Because only one tree (one willow) survived the second year planted in tailings, the $T$ treatment was removed from further statistical analysis regarding trees. For soil characteristics and poplar instantaneous transpiration, data were submitted to one-way ANOVA (treatment effect). For final height and diameter (height and diameter at planting as covariable), leaf water potentials, tree biomass, and $813 \mathrm{C}$, the data were submitted to two-way ANOVA (treatment $\times$ species). Two ANOVAs were performed on the root data: two-way (treatment $\times$ species) on the superficial samples (0-20 cm depth) and three-way (treatment $\times$ species $\times$ depth) on all the samples. No roots (one willow core with root among six sampled) were found in the tailings under the mixed tailings and compost. Thus, the TC treatment was removed from the analysis of the species by treatment by sampling depth effect. Substrate VWC and water saturation data of 2013 (during $22 \mathrm{wk}$ ) and 2012 (during $7 \mathrm{wk}$ ) were submitted to three-way ANOVA (depth $\times$ treatment $\times$ date). The seven common weeks of measurements for both years were submitted to four-way ANOVA (depth $\times$ treatment $\times$ date $\times$ year). Finally, the VWC and water saturation of the soil layers and mixed tailings and compost were submitted to two-way ANOVA (treatment $\times$ date). Two sets of data (VWC and water saturation) were considered separately for the $50-\mathrm{cm}$ topsoil layer: at $10 \mathrm{~cm}$ from the surface and at $40 \mathrm{~cm}$ from the surface ( $5 \mathrm{~cm}$ above the underlying tailings).

All tested factors were fixed effects, and the block factor was considered a random effect. When effects were significant for a given variable, least-square means were estimated, and Tukey tests were conducted to separate the means. Overall significance for analyses was set to $\alpha=0.05$. All analyses were performed using SAS V.9.2 (SAS Institute Inc.), and repeated measures were used where appropriate.

\section{Results}

\section{Tree Survival and Growth}

After two growing seasons, all trees were dead when directly planted in the tailings ( $\mathrm{T}$ treatment) (Fig. 2). For both species (poplar and willow), the survival rates were similar and greater than $90 \%$ in all soil treatments (TS20, TS50, MS20, TSho), whereas poplar survival declined in the mixed tailings and compost (TC) during the first year. Willow survival was maximal in all treatments except tailings for both years.

For both species, the thick layer treatment (TS50) always gave the highest final height, diameter (Fig. 3), and foliar biomass (Table 2), and the TC treatment gave the lowest performance compared with all the other treatments. The thin soil layer treatments (TS20, MS20) yielded intermediate results except for poplar diameter. In the short term $(2 \mathrm{yr})$, no growth difference was found between trees planted in a $20-\mathrm{cm}$ topsoil layer and topsoil plantation holes.

\section{Tree Water Stress and Gas Exchanges}

The water potential and gas exchange measurements were taken on 3 and 5 July 2013 after 2 wk with less than $10 \mathrm{~mm}$ precipitation. At both dates the volumetric water content of all the substrates (20-38\%) was the lowest of all the growing season (from the beginning of June to the end of September) according to the EC-5 probes' continuous records (Fig. 4). The species or date did not influence the water potential of trees (i.e., there was no significant interaction between species, treatment, and date). Foliar water potential (both species) and instantaneous transpiration (poplar) were similar among treatments (Table 2). Poplar had stopped its photosynthesis at the time of measurements; 

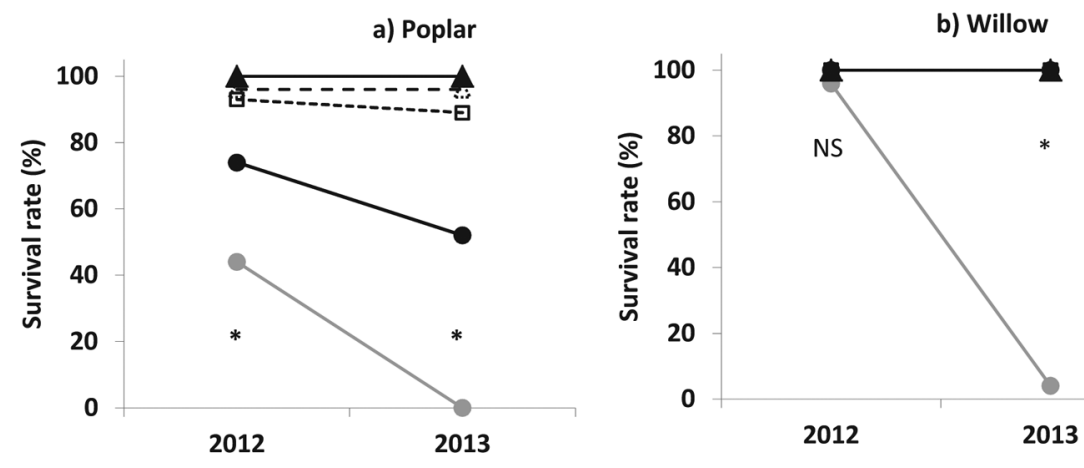

--ษ--MS20
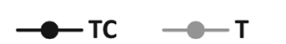

TS50

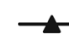

TS20

no net $\mathrm{CO}_{2}$ assimilation occurred (results not shown). Both tree species showed no variation of $\delta^{13} \mathrm{C}$ among treatments, but poplar had significantly greater total leaf area in TS50 (Table 2) compared with other treatments.

\section{Root Development of Trees}

For all thin soil layer treatments (TS20, TSho, MS20), tree roots were always found in cores taken in the underlying tailings, but this was not the case under the compost mixed with tailings (TC) treatment. Both species' responses to treatments were similar because there was no significant interaction between the treatment and species. We found no significant differences in root morphological parameters among the substrates above the
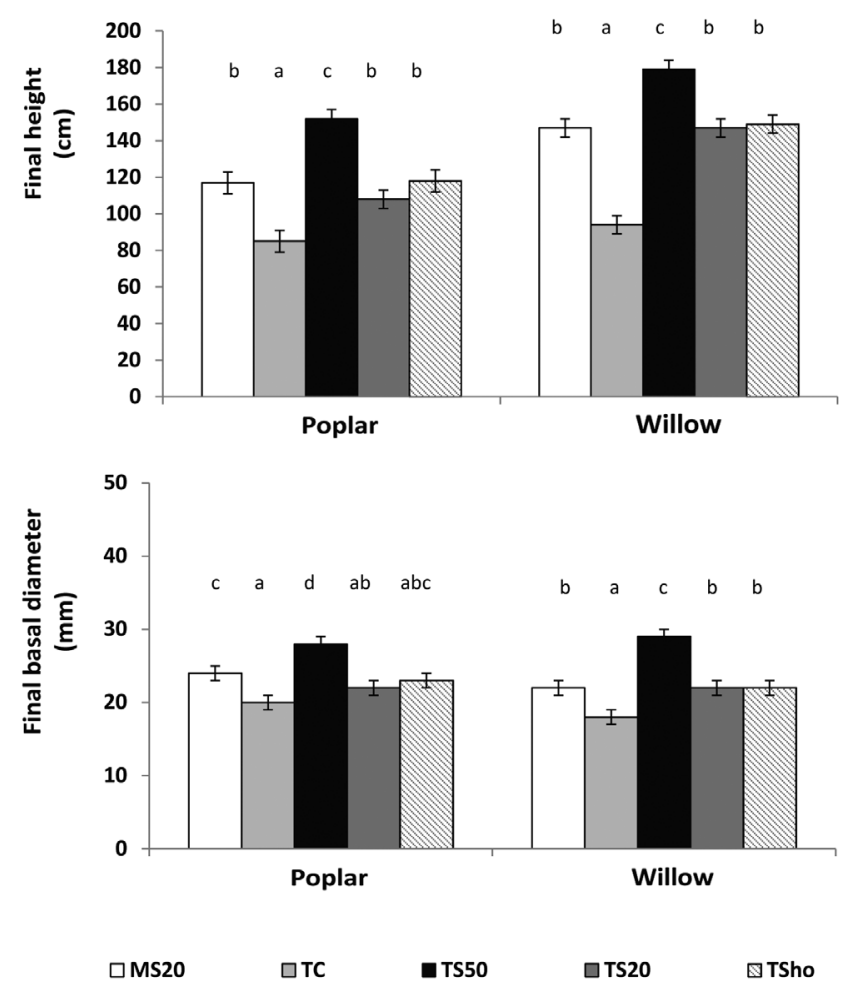

Fig. 3. Tree height $(\mathrm{cm})$ and basal diameter $(\mathrm{mm})$ among treatments ( $20 \mathrm{~cm}$ mineral soil mixed with compost [MS20], compost and tailings mixture [TC], topsoil layer $20 \mathrm{~cm}$ [TS20], topsoil layer $50 \mathrm{~cm}$ [TS50], topsoil plantation holes [TSho]) at the end of the second growing season (2013) for (a) DN $\times$ M poplar and (b) basket willow. Values are means $(n=27)$. Bars denote SE. Statistical comparisons were done among treatments at each date, and treatments denoted by the same letter do not significantly differ at $P=0.05$.
Fig. 2. Tree survival rate (\%) among treatments (20 cm mineral soil mixed with compost [MS20], tailings alone $[\mathrm{T}]$, compost and tailings mixture [TC], topsoil layer $20 \mathrm{~cm}$ [TS20], topsoil layer $50 \mathrm{~cm}$ [TS50], topsoil plantation holes [TSho]) at each growing season (2012: first growing season; 2013: second growing season) for (a) DN $\times$ M poplar and (b) basket willow. Values are means $(n=27)$. Statistical comparisons were done among treatments at each date. ${ }^{*} P<$ 0.05. NS, nonsignificant. tailings (soil layers or compost mixed with tailings) (Table 3). We also found no significant difference among root parameters when cores were taken deeper than $20 \mathrm{~cm}$ in the substrate profile compared with superficial $(0-20 \mathrm{~cm})$ cores, except for the root tip density, which was significantly lower in deeper cores (Table $3)$. However, regarding the cores at $>20 \mathrm{~cm}$ depth, there was no difference between root tip density in the tailings under the soil layers and in the lowest part of the thick topsoil layer (TS50).

\section{Substrate Structure, Volumetric Water Content, and Saturation}

Tailings ( $\mathrm{T})$ showed greater bulk density $\left(1.33 \mathrm{~g} \mathrm{~cm}^{-3}\right)$ and lower total porosity (47\%), macroporosity (6\%), and permanent wilting point $(2 \%)$ compared with the other treatments (Table 4). The substrates' electrical conductivity increased from topsoil to tailings or mineral soil mixed with compost (Table 4). The organic matter concentration of tailings or mineral soil mixed with compost did not differ significantly from those in tailings and remained lower than those found in the topsoils (Table 4).

All the probes installed in the tailings (tailings under a treatment layer or without any layer) gave similar VWC values (2013, 22 wk of measurement [Fig. 4]; 0.31-0.36 mL mL ${ }^{-1}$ ). Regarding the treatment layers, the $10-\mathrm{cm}$-deep probes installed in the tailings mixed with compost (TC) and the thick topsoil layer (TS50) gave similar VWC and water saturation values in 2013 (Table 5), which were lower than values given by the probes installed at the same depth in the other treatment layers (MS20, TS20, TSho) or $40 \mathrm{~cm}$ deep in the thick topsoil layer (TS50). Volumetric water content and water saturation significantly decreased in the three topsoil layers (TS20, TS50, and TSho, $-10 \%$ of water saturation) and their underlying tailings ( -14 to $-20 \%$ of water saturation) from 2012 to 2013, whereas they were similar for both years in the MS20, TC, and T treatments. During both years of the experiment and whatever the treatment, the water saturation of the tailings remained above $25 \%$ and near or above $20 \%$ in the soil layers and tailings mixed with compost (Fig. 4), which is above tailings, MS20, or TC permanent wilting point thresholds but closer to the one of topsoil (Table 4).

\section{Discussion}

Surprisingly, and contrary to our third hypothesis, both tree species developed roots in the tailings underlying the thin soil treatments. Moreover, the studied morphological characteristics of these roots were similar to those of roots sampled at the same 
depth in the thick soil layer treatment; however, large variability between replicates may have affected the treatment comparison. Yet, corresponding to our first hypothesis, tailings showed density close to the threshold impeding root growth $\left(1.4 \mathrm{~g} \mathrm{~cm}^{-3}\right)$ (Archer and Smith, 1972), and air-filled porosity values were lower than the minimum required for root development $(10 \%$ v/v) (Archer and Smith, 1972). However, tailings also showed a mean water saturation of $77 \%$ (Table 3), which left $23 \%$ of pores available for air circulation and which may have facilitated root

Table 2. Indicators of water stress exposure (measured in July 2013) and foliar characteristics (measured at the end of the second growing season, September 2013) for both planted tree species among treatments.

\begin{tabular}{|c|c|c|c|c|c|}
\hline & \multicolumn{5}{|c|}{ Treatment $\dagger$} \\
\hline & MS20 & TSho & TS50 & TS20 & TC \\
\hline \multicolumn{6}{|c|}{ Indicators of water stress exposure } \\
\hline \multicolumn{6}{|l|}{ Foliar water potential, $\mathrm{MPa}$} \\
\hline Poplar & $-1.3(0.1) a \neq$ & $-1.1(0.1) a$ & $-1.1(0.1) \mathrm{a}$ & $-1.0(0.1) a$ & $-1.4(0.1) a$ \\
\hline Willow & $-1.1(0.1) a$ & $-1.2(0.1) a$ & $-1.2(0.1) a$ & $-1.2(0.1) a$ & $-1.1(0.1) a$ \\
\hline Poplar instantaneous transpiration, $\mathrm{mmol} \mathrm{m}^{-2} \mathrm{~s}^{-1}$ & $3.3(0.3) a$ & $3.7(0.3) \mathrm{a}$ & $4.0(0.3) a$ & $4.1(0.3) \mathrm{a}$ & $3.8(0.3) a$ \\
\hline \multicolumn{6}{|l|}{ Carbon isotope composition } \\
\hline Poplar & $-27.4(0.5) \mathrm{a}$ & $-27.6(0.5) a$ & $-27.8(0.5) a$ & $-26.5(0.5) \mathrm{a}$ & $-25.6(0.5) a$ \\
\hline Willow & $-29.1(0.5) \mathrm{a}$ & $-29.7(0.5) a$ & $-29.3(0.5) a$ & $-29.8(0.5) a$ & $-29.8(0.5) a$ \\
\hline \multicolumn{6}{|c|}{ Foliar characteristics } \\
\hline \multicolumn{6}{|l|}{ Total leaf area, $\mathrm{cm}^{2}$} \\
\hline Poplar & 4034 (925)a & 4356 (925)a & $8992(925) b$ & 3929 (925)a & $1319(925) a$ \\
\hline Willow & $5115(1433) a$ & 4602 (1433)a & $9322(1433) b$ & 3130 (1433)a & $1238(1433) a$ \\
\hline \multicolumn{6}{|l|}{ Total leaf biomass, $\mathrm{g}$} \\
\hline Poplar & $57(9) \mathrm{b}$ & $46(9) b$ & $105(9) \mathrm{c}$ & $32(9) a b$ & $16(9) a$ \\
\hline Willow & $34(9) \mathrm{b}$ & $44(9) \mathrm{b}$ & $84(9) \mathrm{c}$ & 45 (9)ab & $11(9) a$ \\
\hline \multicolumn{6}{|l|}{ Specific leaf area, $\mathrm{cm}^{2} \mathrm{mg}^{-1}$} \\
\hline Poplar & $0.09(0.01) a$ & $0.09(0.01) a$ & $0.08(0.01) a$ & $0.09(0.01) a$ & $0.09(0.01) \mathrm{a}$ \\
\hline Willow & $0.09(0.01) a$ & $0.10(0.01) a$ & $0.11(0.01) a$ & $0.10(0.01) a$ & $0.09(0.01) a$ \\
\hline
\end{tabular}

† MS20, $20 \mathrm{~cm}$ mineral soil mixed with compost;TC, compost and tailings mixture; TS20, topsoil layer $20 \mathrm{~cm}$; TS50, topsoil layer $50 \mathrm{~cm}$; TSho, topsoil plantation holes.

‡ Values are mean $(\mathrm{SE})(n=3)$. Treatments followed by the same lowercase letter do not significantly differ at $P=0.05$.

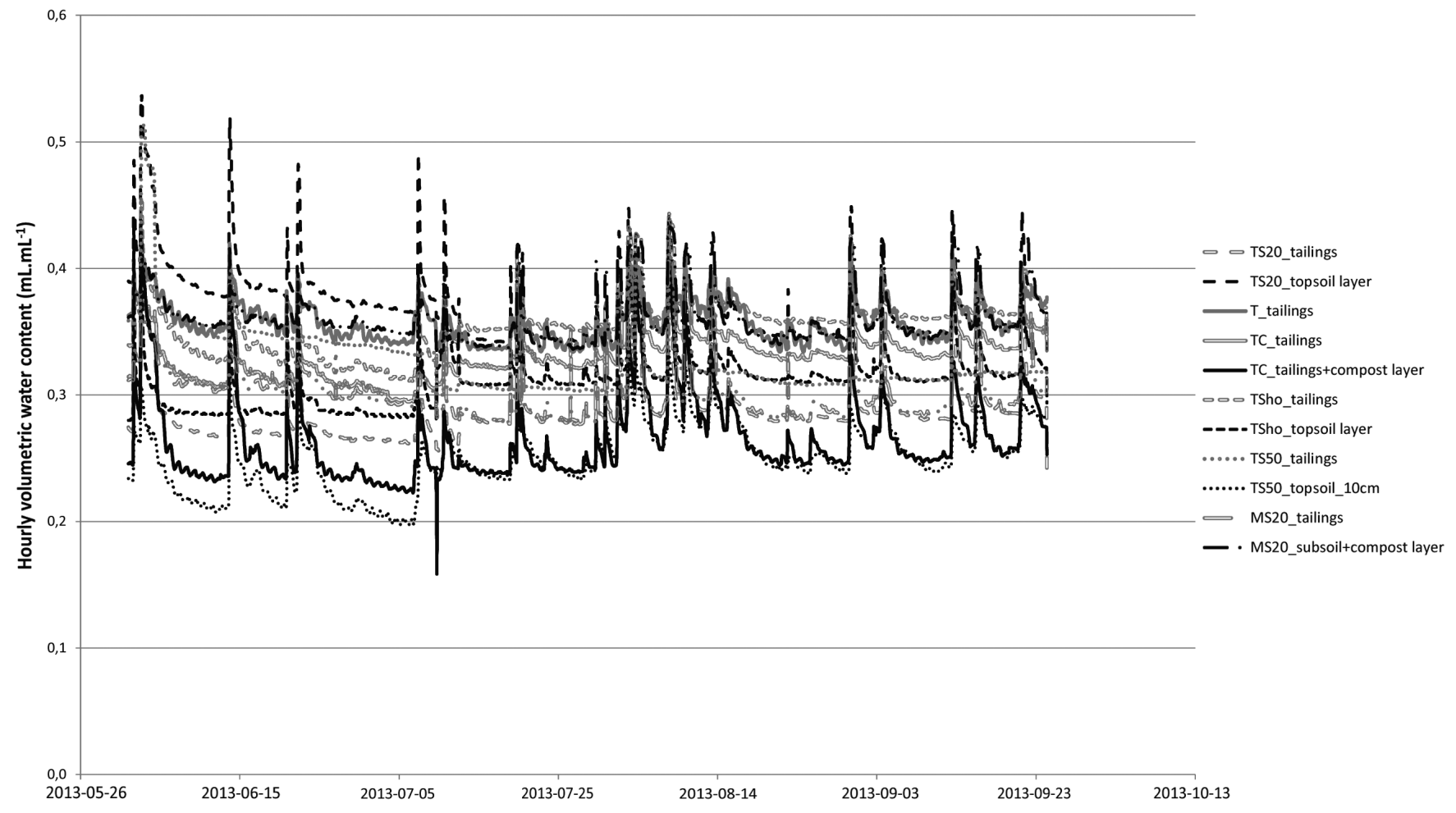

Fig. 4. Substrate volumetric water content (hourly measures) among treatments ( $20 \mathrm{~cm}$ mineral soil mixed with compost [MS20], tailings alone [T], compost and tailings mixture [TC], topsoil layer $20 \mathrm{~cm}$ [TS20], topsoil layer $50 \mathrm{~cm}$ [TS50], topsoil plantation holes [TSho]) during the second growing season (May-October 2013) measured by EC-5 probes placed in the treatment layer and in the underlying tailings (see Fig. 1 for details). Values are means $(n=3)$. 
Table 3. Morphological parameters of roots measured at the end of the second growing season (September 2013) for bulk planted tree species among treatments (at two sampling depth $(0-20 \mathrm{~cm}$ and $>20 \mathrm{~cm}$ ).

\begin{tabular}{|c|c|c|c|c|c|c|c|c|}
\hline & \multicolumn{8}{|c|}{ Treatment $†$} \\
\hline & \multicolumn{2}{|c|}{ TS20 } & \multicolumn{2}{|c|}{ TS50 } & \multicolumn{2}{|c|}{ TSho } & \multicolumn{2}{|c|}{ MS20 } \\
\hline & Soil layer & Tailings & Soil layer & Tailings & Soil layer & Tailings & Soil layer & Tailings \\
\hline & $0-20 \mathrm{~cm}$ & $>20 \mathrm{~cm}$ & $0-20 \mathrm{~cm}$ & $>20 \mathrm{~cm}$ & $0-20 \mathrm{~cm}$ & $>20 \mathrm{~cm}$ & $0-20 \mathrm{~cm}$ & $>20 \mathrm{~cm}$ \\
\hline Root mean diameter, mm & $0.42(0.04) a \neq$ & $0.57(0.05) a$ & $0.47(0.04) a$ & $0.42(0.04) a$ & $0.47(0.04) a$ & $0.40(0.05) \mathrm{a}$ & $0.41(0.05) \mathrm{a}$ & $0.42(0.05) a$ \\
\hline Root length density, $\mathrm{cm} \mathrm{cm}^{-3}$ & $0.55(0.12) \mathrm{a}$ & $0.17(0.14) a$ & $0.49(0.12) \mathrm{a}$ & $0.35(0.12) a$ & $0.49(0.12) a$ & $0.33(0.14) \mathrm{a}$ & $0.36(0.14) \mathrm{a}$ & $0.32(0.14) a$ \\
\hline Root soil density, $\mathrm{g} \mathrm{m}^{-3}$ & 196 (110)a & 80 (136)a & 455 (110)a & $92(110) a$ & 370 (139)a & 312 (136)a & 151 (124)a & 81 (124)a \\
\hline Root tip density, $\mathrm{nb} \mathrm{cm}^{-3}$ & $3.1(1.3) b$ & $0.9(1.5) a$ & $4.4(1.3) b$ & $2.3(1.3) \mathrm{a}$ & $2.6(1.3) b$ & $1.3(1.5) \mathrm{a}$ & $4.2(1.5) b$ & $1.5(1.5) \mathrm{a}$ \\
\hline Specific surface area $(<1 \mathrm{~mm}), \mathrm{cm}^{2} \mathrm{~g}^{-1}$ & 302 (145)a & 285 (179)a & 159 (145)a & 606 (145)a & 107 (183)a & 420 (179)a & 415 (164)a & 426 (164)a \\
\hline Specific root length $(<1 \mathrm{~mm}), \mathrm{cm} \mathrm{g}^{-1}$ & 3571 (1386)a & 3002 (1709)a & 2085 (1386)a & 6785 (1386)a & 1356 (1748)a & 4775 (1707)a & 4806 (1562)a & 4540 (1562)a \\
\hline
\end{tabular}

† MS20, $20 \mathrm{~cm}$ mineral soil mixed with compost;TC, compost and tailings mixture; TS20, topsoil layer $20 \mathrm{~cm}$; TS50, topsoil layer $50 \mathrm{~cm}$; TSho, topsoil plantation holes.

‡ Values are mean (SE) $(n=6)$. Treatments followed by the same lowercase letter do not significantly differ at $P=0.05$.

respiration. Based on these results, root development of trees is possible in tailings despite their poor structural properties.

However, this development may not be systematic because we observed very poor root development in tailings under the compost and tailings mixture. This difference in root development was not due to water saturation in tailings under the different surface treatments. Indeed, contrary to our second hypothesis, the presence of soil layers above tailings did not increase VWC by limiting water evaporation at the surface. Similarly, the compost and tailings mixture at the surface had no effect on the underlying tailings' VWC compared with tailings alone. The formation of a crust was observed at the surface of the tailings without treatment and could have limited water evaporation as well. Crust formation can occur at tailings surface due to salt accumulation in the first 10 to $20 \mathrm{~cm}$ of tailings and precipitation at the tailings surface after water evaporation (Newson and Fahey, 1997; Simms et al., 2007). This salt accumulation could have participated in tree death when planted in tailings by decreasing tailings' water potential. The lack of root development under compost and tailings mixture was not due to differing structure. Structural properties of the compost and tailings

Table 4. Substrate structural and water retention properties as well as electrical conductivity and organic matter concentration among treatments in July 2012.

\begin{tabular}{|c|c|c|c|c|c|c|}
\hline \multirow{2}{*}{ Treatments $\dagger$} & \multicolumn{6}{|c|}{ Properties‡ } \\
\hline & Bulk density & Total porosity & Macroporosity & PWP & EC & OM \\
\hline & $\mathrm{g} \mathrm{cm}^{-3}$ & - & $-\%$ & - & $\mathrm{cS} \mathrm{m} \mathrm{m}^{-1}$ & $\%$ \\
\hline $\mathrm{T}$ & $1.3(0.1) c \S$ & 47 (1)a & $6(1) a$ & $2(0.1) a$ & $10(1) b c$ & $0.1(2) a$ \\
\hline TS50 & $0.9(0.1) a$ & $58(2) c$ & $15(1) b$ & $21(5) b$ & 7 (1)ab & $14(2) c$ \\
\hline TS20 & $0.9(0.1) a b$ & $54(2) b c$ & $14(1) b$ & 18 (6)ab & $5(1) a$ & $12(2) c$ \\
\hline TSho & $1.0(0.1) a b$ & $55(1) b c$ & $13(1) b$ & 15 (1)ab & 8 (1)abc & $11(2) b c$ \\
\hline MS20 & $1.1(0.1) \mathrm{bc}$ & 50 (3)ab & $12(1) b$ & 7 (2)ab & $10(1) \mathrm{bc}$ & 5 (2)ab \\
\hline $\mathrm{TC}$ & $0.9(0.1) a$ & $57(3) c$ & $12(1) b$ & $8(2) a b$ & $13(1) c$ & $4(2) a$ \\
\hline
\end{tabular}

† MS20T, $20 \mathrm{~cm}$ mineral soil mixed with compost; T, tailings alone; TC, compost and tailings mixture; TS20, topsoil layer $20 \mathrm{~cm}$; TS50, topsoil layer $50 \mathrm{~cm}$; TSho, topsoil plantation holes.

‡ EC, electrical conductivity; OM, organic matter; PWP, permanent wilting point.

$\S$ Values are mean (SE) $(n=6)$. Treatments followed by the same lowercase letter do not significantly differ at $P=0.05$.

Table 5. Substrate mean volumetric water content and water saturation among treatments (along the second growing season (May-Oct. 2013) measured by EC-5 probes at differing positions (above or under the tailings surface).

\begin{tabular}{|c|c|c|c|c|c|}
\hline Treatment $\dagger$ & Substrate & $\begin{array}{c}\text { Probe depth } \\
\text { from the surface }\end{array}$ & $\begin{array}{c}\text { Probe position relative to the } \\
\text { underlying tailings }\end{array}$ & VWC $\neq$ & Water saturation \\
\hline & & $\mathrm{cm}$ & & $\mathrm{mL} \mathrm{mL^{-1 }}$ & $\%$ \\
\hline $\mathrm{T}$ & tailings & 5 & $5 \mathrm{~cm}$ under the tailings surface & $0.36(0.02) c \S$ & $77(3) d$ \\
\hline TS20 & topsoil & 12 & $5 \mathrm{~cm}$ above the tailings surface & $0.39(0.02) d$ & $67(3) c$ \\
\hline TS50 & topsoil & 40 & $5 \mathrm{~cm}$ above the tailings surface & $0.38(0.02) \mathrm{cd}$ & $66(3) c$ \\
\hline TS50 & topsoil & 10 & $35 \mathrm{~cm}$ above the tailings surface & $0.27(0.02) a$ & $46(3) a$ \\
\hline TSho & topsoil & 15 & $5 \mathrm{~cm}$ above the tailings surface & $0.33(0.02) \mathrm{b}$ & $57(3) b$ \\
\hline MS20 & mineral soil + compost & 16 & $5 \mathrm{~cm}$ above the tailings surface & $0.37(0.02) \mathrm{cd}$ & $74(3) d$ \\
\hline $\mathrm{TC}$ & tailings + compost & 11 & $5 \mathrm{~cm}$ above the tailings surface & $0.27(0.02) a$ & $48(3) a$ \\
\hline
\end{tabular}

+ MS20, $20 \mathrm{~cm}$ mineral soil mixed with compost; T, tailings alone; TC, compost and tailings mixture; TS20, topsoil layer $20 \mathrm{~cm}$; TS50, topsoil layer $50 \mathrm{~cm}$;

TSho, topsoil plantation holes.

¥ Volumetric water content.

$\S$ Values are mean (SE) $(n=3)$. Treatments followed by the same lowercase letter do not significantly differ at $P=0.05$. 
mixture were similar to those of topsoil or the mixture of mineral soil and compost (Table 4).

Contrary to our fourth hypothesis, neither short-term (water potential and instantaneous transpiration) nor long-term $\left(\delta^{13} \mathrm{C}\right)$ indicators of water stress exposure in trees were sensitive to the decrease of soil volume. Even at low foliar water potentials, poplars kept their stomata open (positive Ei), showing an anisohydric behavior (Tardieu and Simonneau, 1998) that did not restrict $\mathrm{CO}_{2}$ entry into leaves and therefore may have decreased the accuracy of $\delta^{13} \mathrm{C}$ as a long-term indicator of water stress exposure (Farquhar et al., 1989) for this species. Indeed, $\delta^{13} \mathrm{C}$ increases when stomata close due to water stress exposure because intercellular spaces beneath closed stomata become increasingly enriched in ${ }^{13} \mathrm{CO}_{2}$, which results in greater levels of its fixation (Farquhar et al., 1989). Concomitantly, no variation in tree root indicators of water stress exposure (e.g., SRL, SSA, and RLD) was evidenced among treatments in our study. Because trees were able to develop roots in tailings under the soils, water uptake was not limited to the soil, and its volume did not affect the measured indicators of tree water stress exposure. Thus, a thicker topsoil layer did not increase the available water reserve for trees, but trees had larger aboveground dimensions and had a greater total leaf area when grown in the thick topsoil compared with all other treatments. On compost and tailings mixtures, tree root development was restricted to the surface mixture, but this did not result in a significant decrease in foliar water potentials, probably due to decreased aboveground growth of the same trees. Indeed, under water stress, decreased aboveground growth and leaf area decreases the transpiring surface of woody species and allows water conservation (Pallardy, 2008).

Whatever the treatment, the values of foliar water potential measured in our experiment were lower than drought thresholds reported by several authors $(-0.6$ to $0.7 \mathrm{MPa}$ for several poplars [Ridolfi and Dreyer, 1997; Larchevêque et al., 2011] and - 1.0 MPa for willow [Ögren and Öquist, 1985]), especially for poplars. These results indicate that all planted trees showed symptoms of water stress when the measures were taken after 2 wk with low precipitation despite important water storage in tailings. The cause of low foliar water potentials of trees is unclear because water saturation of the tailings always remained far above the permanent wilting point with acceptable electrical conductivity levels ( $40 \mathrm{cS} \mathrm{m} \mathrm{m}^{-1}$ reported threshold for impeding root survival) (Epstein et al., 1976; Jordan et al., 2008). Thus, water was available from tailings for root uptake at all times during the experiment. Intense wind exposure on mine sites, vast surfaces without any sheltering vegetation, could have exposed trees to greater air temperature and vapor pressure deficit (Kapos, 1989), decreasing foliar water potential.

In compost mixtures with tailings or mineral soil, water saturation also remained clearly above the permanent wilting point, whereas it sometimes decreased at the permanent wilting point level in topsoil treatments. Trees growing in topsoils thus may have pumped more water from underlying tailings to compensate for lower available water in topsoil as well as greater leaf biomass (i.e., probable greater water loss; Table 2), which decreased water saturation of tailings. Thus, contrary to our second hypothesis, the presence of topsoil layers planted with broadleaf trees decreased water saturation of tailings after the first year of plantation.

\section{Conclusion}

Our main finding is that roots were able to colonize underlying mine tailings when trees were planted in soil layers. Moreover, the change of growing substrate for roots did not result in morphological changes of the roots. However, the nature of the substrate above tailings influenced root colonization of tailings because it was impeded when trees were planted in the compost and tailings mixture. In this mixture, trees, particularly poplar, were also smaller and had lower survival rates. Thus, the use of soil layers, even with limited volume (i.e., plantation holes or limited thickness), should be preferred to tailings improvement with organic amendments. To maximize tree aboveground growth, however, thick soil layers are recommended. Moreover, with soil layers (i.e., topsoil in our experiment) prone to occasional lack of water during the growing season, broadleaf trees could be used to decrease tailings water saturation by root pumping. Finally, trees showed symptoms of water stress despite available water in the tailings colonized by roots, and the causes of these symptoms should be further investigated.

\section{Acknowledgments}

This research was funded by Canadian Malartic mine (previously Osisko Mining Corporation) and the Natural Sciences and Engineering Research Council of Canada (NSERC) through a postdoctoral industrial R\&D fellowship to M. Guittonny-Larchevêque. The authors thank the Université du Québec en Abitibi-Témiscamingue for providing laboratory and technical equipment; the Commission Scolaire Harricana, Amos, QC; and Christine Mirault for assistance in fieldwork.

\section{References}

Agriculture and Agri-Food Canada. 2010. The Canadian system of soil classification, 3rd edition. http://sis.agr.gc.ca/cansis/taxa/cssc3/index.html (accessed 15 Feb. 2016).

Al, T.A., and D.W. Blowes. 1999. The hydrogeology of a tailings impoundment formed by central discharge of thickened tailings: Implications for tailings management. J. Contam. Hydrol. 38:489-505. doi:10.1016/S0169-7722(99)00007-8

Angel, P.N., D.H. Graves, C. Barton, R.C. Warner, P.W. Conrad, R.G. Sweigard, and C. Agouridis. 2006. Surface mine reforestation research: Evaluation of tree response to low compaction reclamation techniques, In: R.I. Barnhisel, editor, Proceedings, 7 th International Conference on Acid Rock Drainage, St. Louis, MO. 26-30 Mar. 2006. American Society of Mining and Reclamation, Lexington, KY. p. $45-58$

Archer, J.R., and P.D. Smith. 1972. The relation between bulk density, available water capacity, and air capacity of soils. J. Soil Sci. 23(4):475-480. doi:10.1111/j.1365-2389.1972.tb01678.x

Asensio, V., F.A. Vega, L. Andrade, and E.F. Covelo. 2011. Tree vegetation to improve physico-chemical properties in bare mine soils. Fresenius Environ. Bull. 20(12):1-20.

Aubertin, M., B. Bussière, and L. Bernier. 2002. Environnement et gestion des résidus miniers. CDrom. Les Éditions de l'École Polytechnique de Montréal, Montreal, QC, Canada.

Aubertin, M., B. Bussière, and R.P. Chapuis. 1996. Hydraulic conductivity of homogenized tailings from hard rock mines. Can. Geotech. J. 33(3):470-482. doi:10.1139/t96-068

Bagatto, G., and J.D. Shorthouse. 1999. Biotic and abiotic characteristics of ecosystems on acid metalliferous mine tailings near Sudbury, Ontario. Can. J. Bot. 77:410-425.

Barbour, S.L., G.W. Wilson, and L.C. St-Arnaud. 1993. Evaluation of the saturatedunsaturated groundwater conditions of a thickened tailings deposit. Can. Geotech. J. 30:935-946. doi:10.1139/t93-091

Bendfeldt, E.S., J.A. Burger, and W.L. Daniels. 2001. Quality of amended mine soils after sixteen years. Soil Sci. Soc. Am. J. 65:1736-1744. doi:10.2136/ sssaj2001.1736

Bjugstad, A.J. 1986. Hybrid poplar cultivars for maximizing phytomass production on gold mine tailings in the Black Hills. In: Proceedings, National Symposium on Mining, Hydrology, Sedimentology, and Reclamation. 8-11 Dec. 1986. University of Kentucky, Lexington.

Borgegard, S.-O., and H. Rydin. 1989. Biomass, root penetration and heavy metal uptake in birch in a soil cover over copper tailings. J. Appl. Ecol. 26(2):585-595. doi: $10.2307 / 2404084$ 
Bouyoucos, G.J. 1962. Hydrometer method improved for making particle-size analysis of soils. Agron. J. 54:464-465. doi:10.2134/agronj1962.00021962005400050028x

Boyter, M.J., J.E. Brummer, and W.C. Leininger. 2009. Growth and metal accumulation of Geyer and mountain willow grown in topsoil versus amended mine tailings. Water Air Soil Pollut. 198:17-29. doi:10.1007/s11270-008-9822-9

Burger, J.A., and C.E. Zipper. 2002. How to restore forests on surface-mined land: Reclamation guidelines for surface mined land in Southwest Virginia. Powell River Series, Publication 460-123. Virginia Cooperative Extension, Arlington.

Bussière, B. 2007. Colloquium 2004: Hydrogeotechnical properties of hard rock tailings from metal mines and emerging geoenvironmental disposal approaches. Can. Geotech. J. 44:1019-1052. doi:10.1139/T07-040

Cassel, D.K., and D.R. Nielsen. 1986. Field capacity and available water capacity. In: A. Klute, editor, Methods of soil analysis. Part 1. Physical and mineralogical methods. Agronomy Series No 9. SSSA, Madison, WI. p. 901-926.

Comas, L.H., S.R. Becker, V.M.V. Cruz, P.F. Byrne, and D.A. Dierig. 2013. Root traits contributing to plant productivity under drought. Front. Plant Sci. 4(442):1-16.

Cooke, J.A., and M.S. Johnson. 2002. Ecological restoration of land with particular reference to the mining of metals and industrial minerals: A review of theory and practice. Environ. Rev. 10:41-71. doi:10.1139/a01-014

Drake, L. 1986. Survival and growth of conservation shrubs and trees with thin-cover reclamation on acid substrate, Iowa, USA. Environ. Geochem. Health 8(3):6267. doi:10.1007/BF02311023

Emerson, P., J. Skousen, and P. Ziemkiewicz. 2009. Survival and growth of hardwoods in brown versus gray sandstone on a surface mine in West Virginia. J. Environ. Qual. 38:1821-1829. doi:10.2134/jeq2008.0479

Epstein, E., J.M. Taylor, and R.L. Chaney. 1976. Effects of sewage sludge and sludge compost applied to soil on some soil physical and chemical properties. J. Environ. Qual. 5:422-426. doi:10.2134/jeq1976.00472425000500040021x

Evanylo, G.K., A.O. Abaye, C. Dundas, C.E. Zipper, R. Lemus, B. Sukkariyah, and J. Rockett. 2005. Herbaceous vegetation productivity, persistence, and metals uptake on a biosolids-amended mine soil. J. Environ. Qual. 34:1811-1819. doi: $10.2134 /$ jeq2004.0329

Farquhar, G.D., J.R. Ehleringer, and K.T. Hubick. 1989. Carbon isotope discrimination and photosynthesis. Annu. Rev. Plant Physiol. Plant Mol. Biol. 40:503537. doi:10.1146/annurev.pp.40.060189.002443

Garg, N., and S. Chandel. 2010. Arbuscular mycorrhizal networks: Process and functions. A review. Agron. Sustainable Dev. 30:581-599. doi:10.1051/agro/2009054

Gibson, D.J. 1982. The natural revegetation of lead/zinc mine spoil in northeastern Oklahoma. Southwest. Nat. 27(4):425-436. doi:10.2307/3670717

Government of Canada. 2004. National climate archives. http://climate.weather. gc.ca/ (accessed 15 Feb. 2016)

Government of Quebec. 2016. Annexe I: Règlement sur la protection et la réhabilitation des terrains, Loi sur la qualité de l'environnement, Chapitre Q2 r.37. www2.publicationsduquebec.gouv.qc.ca/dynamicSearch/telecharge. php?type=3\&file=/Q2/Q2R37.htm (accessed 15 Feb. 2016).

Hutchings, T.R., A.J. Moffat, and R.A. Kemp. 2001. Effects of rooting and tree growth of selected woodland species on cap integrity in a mineral capped landfill site. Waste Manage. Res. 19:194-200. doi:10.1177/0734242X0101900302

Jordan, S.N., G.J. Mullen, and R.G. Courtney. 2008. Utilization of spent mushroom compost for the revegetation of lead-zinc tailings: Effects on physico-chemical properties of tailings and growth of Lolium perenne. Bioresour. Technol. 99:8125-8129. doi:10.1016/j.biortech.2008.03.054

Kapos, V. 1989. Effects of isolation on the water status of forest patches in the Brazilian Amazon. J. Trop. Ecol. 5(2):173-185. doi:10.1017/S0266467400003448

Klute, A. 1986. Water retention: Laboratory methods. In: A. Klute, editor, Methods of soil analysis. Part 1. Physical and mineralogical methods. Agronomy Series No. 9. SSSA, Madison, WI. p. 635-662.

Kost, D.A., J.P. Vimmerstedt, and J.H. Brown. 1998. Site factor effects on establishment of planted and volunteer trees and shrubs on graded cast overburden and replaced topsoil in southeastern Ohio. Int. J. Surf. Min. Reclam. Environ. 12(2):79-86. doi:10.1080/09208118908944027

Landhäusser, S.M., J. Rodriguez-Alvarez, E.H. Marenholtz, and V.J. Lieffers. 2012. Effect of stock type characteristics and time of planting on field performance of aspen (Populus tremuloides Michx.) seedlings on boreal reclamation sites. New For. 43:679-693. doi:10.1007/s11056-012-9346-4

Larchevêque, M., A. Desrochers, B. Bussière, and D. Cimon. 2014. Planting trees in soils above non-acid-generating wastes of a boreal gold mine. Ecoscience 21(3-4):217-231.

Larchevêque, M., A. Desrochers, B. Bussière, H. Cartier, and J.-S. David. 2013. Revegetation of non acid-generating, thickened tailings with boreal trees: A greenhouse study. J. Environ. Qual. 42:351-360. doi:10.2134/jeq2012.0111

Larchevêque, M., A. Desrochers, B. Bussière, H. Cartier, C. Baribeault, C. Pednault, and J.-S. David. 2012. How to grow trees on the wastes of a boreal gold mine: Identification of the main physic-chemical limitations. In: A.B. Fourie and M. Tibbett, editors, Mine closure 2012. Australian Centre for Geomechanics, Perth, Australia. p. 467-480.

Larchevêque, M., M. Maurel, A. DesRochers, and G.R. LaRocque. 2011. How does drought tolerance compare between two improved hybrids of balsam poplars and an unimproved native species? Tree Physiol. 31(3):240-249. doi:10.1093/ treephys/tpr011
Leuschner, C., D. Hertel, I. Schmid, O. Koch, A. Muhs, and D. Hölscher. 2004. Stand fine root biomass and fine root morphology in old-growth beech forests as a function of precipitation and soil fertility. Plant Soil 258(1):43-56. doi:10.1023/B:PLSO.0000016508.20173.80

Marcus, J.J. 1997. Technologies for environmental protection. In: Mining environmental handbook (USA): Effects of mining on the environment and American environmental controls on mining. Imperial College Press, London. p. 190-282.

Meredith, H.L., and W.H. Patrick. 1961. Effects of soil compaction on subsoil root penetration and physical properties of three soils in Louisiana. Agron. J. 53:163-167. doi:10.2134/agronj1961.00021962005300030011x

Michels, A., C. Barton, T. Cushing, P. Angel, R. Sweigard, and D. Graves. 2007. Evaluation of low spoil compaction techniques for hardwood forest establishment on an eastern Kentucky surface mine. In: R.I. Barnhisel, editor, 30 years of SMCRA and beyond. Proceedings, National Meeting of the American Society of Mining and Reclamation, Gillette, WY. 2-7 June 2007. American Society of Mining and Reclamation, Lexington, KY.

Moffat, A.J. 1995. Minimum soil depths for the establishment of woodland on disturbed ground. Arboricultural J. 19:19-27. doi:10.1080/03071375.1995.9756445

Mosseler, A., and J.E. Major. 2014. Coppice growth responses of two North American willows in acidic clay soils on coal mine overburden. Can. J. Plant Sci. 94:12691279. doi:10.4141/cjps-2014-046

Mosseler, A., J.E. Major, and M. Labrecque. 2014. Growth and survival of seven native willow species on highly disturbed coal mine sites in eastern Canada. Can. J. For. Res. 44:340-349. doi:10.1139/cjfr-2013-0447

Newson, T., and M. Fahey. 1997. Salinisation due to evaporation from tailings. In: R.N. Yong and H.R. Thomas, editors, Geoenvironmental engineering: Contaminated ground: Fate of pollutants and remediation. Thomas Telford publishing, London. p. 128-133.

Nicoll, B.C., B.A. Gardiner, B. Rayner, and A.J. Peace. 2006. Anchorage of coniferous trees in relation to species, soil type, and rooting depth. Can. J. For. Res. 36:1871-1883. doi:10.1139/x06-072

Ögren, E., and G. Öquist. 1985. Effects of drought on photosynthesis, chlorophyll fluorescence and photoinhibition susceptibility in intact willow leaves. Planta 166:380-388. doi:10.1007/BF00401176

Olsen, S.R., C.V. Cole, F.S. Watanave, and L.A. Dean. 1954. Estimation of available phosphorus in soils by extraction with sodium bicarbonate. USDA, Washington, DC.

Pallardy, S.G. 2008. Physiology of woody plants. 3rd ed. Academic Press, Burlington, MA.

Peters, T.H. 1995. Revegetation of the Copper Cliff tailings area. In: J. Gunn, editor, Restoration and recovery of an industrial region. Springer, New York. p. 123-133.

Read, D.J., J.R. Leake, and J. Perez-Moren. 2004. Mycorrhizal fungi as drivers of ecosystem processes in heathland and boreal forest biomes. Can. J. Bot. 82:12431263. doi: $10.1139 / \mathrm{b} 04-123$

Renault, S., J. Markham, L. Davis, and M. Martin. 2008. Revegetation of gold mine tailings in Nopiming provincial park, Manitoba. In: R.I. Barnhisel, editor, New opportunities to apply our science. Proceedings, National Meeting of the American Society of Mining and Reclamation, Richmond, VA. 14-19 June 2008. American Society of Mining and Reclamation, Lexington, KY. p. 910.

Ridolfi, M., and E. Dreyer. 1997. Responses to water stress in an ABA unresponsive hybrid poplar (Populus koreana $\times$ trichocarpa cv. Peace). III. Consequences for photosynthetic carbon assimilation. New Phytol. 135:31-40. doi:10.1046/j.1469-8137.1997.00624.x

Robinsky, E., S.L. Barbour, G.W. Wilson, D. Bordin, and D.G. Fredlund. 1991. Thickened sloped tailings disposal: An evaluation of seepage and abatement of acid drainage. In: Proceedings, 2nd International Conference on the Abatement of Acidic Drainage. 16-18 Sept. 1991. Montréal, QC. p. 529-549.

Simms, P., M. Grabinsky, and G. Zhan. 2007. Modelling evaporation of paste tailings from the Bulyanhulu mine. Can. Geotech. J. 44:1417-1432. doi:10.1139/ T07-067

Sloan, J.L., and D.F. Jacobs. 2013. Fertilization at planting influences seedling growth and vegetative competition on a post-mining boreal reclamation site. New For. 44:687-701. doi:10.1007/s11056-013-9378-4

Tardieu, F., and T. Simonneau. 1998. Variability among species of stomatal control under fluctuating soil water status and evaporative demand: Modelling isohydric and anisohydric behaviours. J. Exp. Bot. 49:419-432. doi:10.1093/jxb/49. Special_Issue.419

Tordoff, G.M., A.J.M. Baker, and A.J. Willis. 2000. Current approaches to the revegetation and reclamation of metalliferous mine wastes. Chemosphere 41:219228. doi:10.1016/S0045-6535(99)00414-2

Trüby, P. 2003. Impact of heavy metals on forest trees from mining areas. In: Proceedings, Sudbury 2003: Mining and the Environment III Conference, Sudbury, Ontario, Canada. 25-28 May 2003.

van den Driessche, R. 1999. First-year growth response of four Populus trichocarpa $\times$ Populus deltoïdes clones to fertilizer placement and level. Can. J. For. Res. 29:554-562.

Zhang, Z.Q., W.S. Shu, C.Y. Lan, and M.H. Wong. 2001. Soil seed bank as an input of seed source in revegetation of lead/zinc mine tailings. Restor. Ecol. 9(4):378385. doi:10.1046/j.1526-100X.2001.94007.x 